\title{
Investigation and Research on the quality of life of College Teachers
}

\author{
Zehui Jiang ${ }^{1}$, Jun Zhang,** \\ ${ }^{1}$ Jiangxi University of Traditional Chinese Medicine,Nanchang,Jiangxi,China; \\ ${ }^{2}$ Department of Cardiovascular Medicine,the 94th Hospital of Chinese People's Liberation \\ Army ,Nanchang,Jiangxi,China \\ Communication Author: Jun Zhang
}

Keywords: College Teachers, The quality of life.

\begin{abstract}
In this paper, the quality of living survey by the school teachers as research goal, combined with literature review and questionnaire survey method of Jiangxi University Of Traditional Chinese Medicine were investigated to grind in service teachers, found that most of the teachers subjective satisfaction of currently living and working condition is in a below average level, the paper also talks about the countermeasures how to improve the quality level in the end.
\end{abstract}

\section{Introduction}

At the moment, the educational system is changing constantly with the times. Higher education is also on the edge of social practice and scientific research, which requires the deepening of the reform of colleges and universities. The new educational concept and teaching model put forward higher requirements and challenges for college teachers, and their work, mental and physical pressure also increased. However, the social concern to college teachers is very little. Secondly, the related research are relatively few, lack of universality, imperfect theory, etc..

I hope that through the investigation and study of this subject, I can show the current work and life situation of college teachers, and I hope everyone will have more understanding to the profession of teachers in higher learning institutions. In addition, only researching on the life quality of teachers in university, we can fundamentally understand the crux of the problem, and then puts forward some constructive suggestions, and know how to improve the quality of life and satisfaction of their own.

\section{Object of study}

Based on the investigation and study of the quality of life of college teachers, this paper takes the in-service teachers of Jiangxi University of traditional Chinese medicine as the research sample. A random survey of 120 teachers was conducted. This time we issued 120 questionnaires and collected 83 copies. The questionnaire consists of 22 items, including gender, age, marital status, degree, title, teaching time and other basic conditions and their own health status, living environment, work environment, mental health, social support and other dimensions, each dimension score is divided into very satisfied and satisfied, not satisfied, very dissatisfied etc. level.

\section{Result analysis}

The preliminary statistical results of the questionnaire show that there are 46 males and 37 females, 63 married and 20 unmarried; 25 teaching assistants, 37 lecturers, and 21 associate professors and above titles( See Table 1) 
Table 1 Teachers' gender, marital status and titles

\begin{tabular}{cccccccc}
\hline group & Male & Female & married & $\begin{array}{c}\text { unmarri } \\
\text { ed }\end{array}$ & $\begin{array}{c}\text { Assista } \\
\text { nt }\end{array}$ & lecturer & $\begin{array}{c}\text { Associate } \\
\text { professor and } \\
\text { above }\end{array}$ \\
\hline number & 46 & 37 & 63 & 20 & 25 & 37 & 21 \\
$\begin{array}{c}\text { percentage } \\
\text { (\%) }\end{array}$ & 55.4 & 44.6 & 76.0 & 24.1 & 30.1 & 44.6 & 25.3 \\
\hline
\end{tabular}

There are 43 teachers to evaluate the quality of life satisfact and above, and 40 teachers evaluate general and following, accounting for $48.2 \%$. Among them, lecturers accounted for half of the proportion; $90.4 \%$ of the teachers are satisfied with their ability to work; $74.7 \%$ of the teachers are satisfied with the interpersonal relationship of handling and coordination; $74 \%$ of the teachers are satisfied with their health; the subjective state of mind of their own feel good accounted for $63.9 \%$; the satisfaction of self care ability accounted for $61.5 \%$, and satisfaction of the salary distribution state accounted for $61.4 \%$ ( See Table 2).

Table 2 Teacher self-evaluation and salary satisfaction

\begin{tabular}{cccccccc}
\hline satisfaction & $\begin{array}{c}\text { Qualit } \\
\text { y of } \\
\text { life }\end{array}$ & $\begin{array}{c}\text { Workin } \\
\text { ability }\end{array}$ & $\begin{array}{c}\text { Interper } \\
\text { sonal } \\
\text { relation } \\
\text { ship }\end{array}$ & Health & $\begin{array}{c}\text { Mental } \\
\text { health }\end{array}$ & $\begin{array}{c}\text { Self-car } \\
\text { e }\end{array}$ & $\begin{array}{c}\text { Salary } \\
\text { distrib } \\
\text { ution }\end{array}$ \\
\hline $\begin{array}{c}\text { Satisfaction and } \\
\text { above (\%) }\end{array}$ & 51.8 & 90.4 & 74.7 & 74.0 & 63.9 & 61.5 & 61.4 \\
$\begin{array}{c}\text { General and below } \\
\text { average (\%) }\end{array}$ & 48.2 & 9.6 & 25.3 & 26.0 & 36.1 & 38.5 & 38.6 \\
\hline
\end{tabular}

In daily life, $68.7 \%$ teacher will pay attention to and control their diet; $24.1 \%$ teacher will exercise 4-5 times a week; most of the teachers exercise times concentrated in about 2-3 times one week, $33.7 \%$ teacher is at once a week or less exercise. Dissatisfaction with the quality of sleep accounted for $41 \%$ of the total, and $91.6 \%$ of teachers said that occasionally depression, anxiety and other negative emotions.

In all teacher titles, the fluctuation of instructor level data is the largest and most obvious. In short, in this part of the lecturer, there is a great deal of disagreement about the satisfaction of certain subjective indicators. This is closely related to the professional nature of the lecturer. Some lecturers are not unilateral employees of the school, and teachers are their second profession. In this case, some teachers of basic medicine is in the hospital physician, their workload and even reach the load state, the spiritual and psychological and social expectations, teacher occupation pressure is much more than ordinary teachers.

At the end of a set of data, if you synthesizing all (physiological, psychological and social relations and environmental aspects), make a score to the quality of life of their own. 85 points and above have 20 teachers, $70-85$ points have 58 teachers, 70 points below have 58 teachers. That is to say, in these 83 survey samples, $69.9 \%$ of teachers think their quality of life is at a general level.

\section{Improve the quality of life of teachers Countermeasures}

Standing on the starting point of teacher's interests, understanding the real needs of teachers and meeting their reasonable needs is an important way to improve teachers' sense of happiness and satisfaction. Only when teachers' groups are concerned and cared, can they feel the need and sense 
of existence. Fully consider the primary and secondary needs of teachers in different age groups, including career prospects and planning development. They also give young teachers the opportunity to try their potential and demonstrate their ability to work.

Strive to create a comfortable working environment and a just, peaceful and harmonious environment for teachers. Managers should respect, trust and actively care for teachers. In the daily work life, managers should be more into the "masses", concerned about the lives of teachers, help solve practical difficulties. Managers should take the lead in creating a good and comfortable atmosphere of the organization, it will also be beneficial to the physical and mental health of teachers and efficient work.

The pressure of work load is easy to lead the teacher to be in the sub-health state of physical and psychological disharmony. How to organize the work effectively is not only closely related to the system, the ability of teachers and colleagues, but also requires the teachers to bear their own psychological and compressive ability. Coordinate workload, provide an organizational environment that strengthens physical exercise and psychological guidance, and improves physical and mental health. Guide teachers to develop an active, healthy and self regulating function.

At present, the salary structure of university teachers is unreasonable, the proportion of fixed wages is high, and the allowance is less. When the teacher does not get the project from the allowance, the reward, he will seek the way from the schoolwork, the periphery. Thus, a teacher has become a salesman who has completed the assessment target during the period, and the teacher's energy and time can not be better focused on teaching and scientific research. Improving the quality of teaching and the amount of scientific research will lead to more job stress and the result of a line feed. The teacher is a profession with high social expectation and sense of responsibility, however, this often leads to the embarrassment and choice faced by the college teachers. Therefore, as a university teacher, he should be guaranteed income standards of living income, and even a high level of external competitiveness. The salary structure should be adjusted, the incentive system should be established, and the humanized welfare benefits should be improved. The personal value and social value of college teachers should be matched with the salary level.

From the point of view of the school administration, we can set up a quality of life group, which is responsible for the quality of teachers' work and life, which is a very effective and referential measure for improving the quality of teachers' work and life. This group is responsible for the communication and communication with teachers, and at any time and truly understand the needs and satisfaction of teachers in teaching and life, and work out a reasonable program to solve the problems of teachers. Only in this way can we meet the interests of most college teachers and improve the quality of life in the work and life of teachers.

After arriving at the statutory retirement age, some teachers can return to school on condition and personal will. At this time, it is necessary to make reasonable arrangements for teaching tasks and implement reasonable remuneration package. Secondly, we can enrich and guide the retirement of teachers living, such as family relations, mediation, curriculum training, hobbies, and the participation of older community activities. Through the guidance and curriculum training, in order to meet the retirement staff better adapt to retirement life, improve the quality of life for elderly teachers.

\section{Acknowledgments}

Related subjects: Jiangxi University Humanities and social science research project (GL1566).

\section{References}

[1] Jia Haiwei. Fuzzy comprehensive evaluation model of College Teachers' quality of work life [J]. Chinese Journal of South China Agricultural University (SOCIAL SCIENCE EDITION), 2005, 4 (3): 87-93.

[2] Li Yongsheng. Stress analysis and Countermeasures of young teachers in newly established 
universities [J]. Western China Science and Technology (Academic), 2007 (6): 22.

[3] Tian Yurong. Current situation and Countermeasures of mental health of college teachers [J]. Journal of Beijing Normal University (SOCIAL SCIENCE EDITION), 2003, 3

[4] Zheng Wei, Yao Longlong. Investigation on the current situation of Vocational College Teachers' quality of life (Anhui Business College of Vocational Technology case) [J]. Journal of Jixi University, 2011, 1 (1): 11.

[5] Luo Ruguo. Study on quality of life of teachers: review and reflection [J]. Journal of Northwest Normal University (SOCIAL SCIENCE EDITION), 2010, 1. 